\title{
PRINSIP DEKLARATIF PENDAFTARAN HAK CIPTA: Kontradiksi Kaedah Pendaftaran Ciptaan dengan Asas Kepemilikan Publikasi Pertama Kali
}

(Declarative Principle on Copyright Registration: Contradiction between the creation and First Publication Principle)

\author{
Suyud Margono \\ Fakultas Hukum Universitas Tarumanagara \\ dan Magister Ilmu Hukum Universitas Mpu Tantular dan Universitas Parahyangan
}

Naskah diterima: 10 Mei 2012; revisi: 03 Juli 2012; disetujui: 20 Juli 2012

\begin{abstract}
ABSTRAK
Hukum Hak Cipta Indonesia memiliki regulasi tentang Pendaftaran Hak Cipta. Pendaftarannya bisa dilakukan oleh pemohon baik Pencipta atau Pemegang Hak Cipta ke Direktorat Jenderal Kekayaan Intelektual. Sertifikat Pendaftaran Hak Cipta menjadi alat bukti jika terjadi sengketa melalui proses penyelesaian di Pengadilan atau non-pengadilan. Ketentuan Pendaftaran Ciptaan ini tidak seimbang dan mengeyampingkan keberadaan karya-karya Cipta yang tidak didaftarkan dalam jumlah jutaan. Sebenarnya, dalam prinsip universal dan perlindungan hak cipta internasional tidak mewajibkan untuk setiap pendaftaran bagi penciptaan kepada lembaga di satu negara tertentu. Sebuah doktrin universal yang digunakan, untuk perlindungan hak cipta telah mendapat perlindungan hukum setelah dibuat, dan dapat diketahui, didengar, dilihat oleh pihak lain. Prinsip ini dikenal dengan Prinsip Deklaratif. Ini berarti ekspresi penciptaan memiliki perlindungan sejak publikasi pertama kalinya. Oleh karena itu, berdasarkan permasalah pertentangan antara Pendaftaran Hak Cipta dan perlindungan penciptaan yang mengikuti sistem deklaratif, maka perlu pemikiran ulang pengaturan pendaftaran hak cipta yang bertentangan dengan kepemilikan hak cipta yang didapat sejak saat penciptaan pertama dipublikasikan.

Kata Kunci: Perlindungan, Kekayaan Intelektual, Hak Cipta, Pendaftaran, Prinsip Deklaratif
\end{abstract}

\section{ABSTRACT}

Indonesian Copyright Law has regulation about Copyright Registration. Its registration can be done by applicant(s) even Creator or the Owner of Copyrights to Directorate General Intellectual Property (Indonesia IP Office). Certificate of Creature Registration will make easy proved if dispute happening event takes proceedings at Court or non-court settlement. This rule of Copyright Registration made in-balance for the un-register creation in fact a million creation that doesn't listed in General of registered creature. Actually, in universal principle and based on international convention concerning copyright protection not knows or not make compulsory for any sense registration for creation or given authority to the institution at one particular state. An Universal doctrine that is utilized for copyright protection which is a creature has gotten law protection since that creature finish is made, and gets to be known, heard, seen by other Party this principle recognised with Declarative Principal. Its mean a that creation is not an ideas but constitute protected expression of ideas or have protection since first time publication, but especially at Indonesia has rule and mechanism of copyrights Registration event its registration is not compulsary. Therefore, based on problematic contradicting among Copyright Registration and protection of creation that follow declarative system this research is rethinking the existence copyright registration rule causes to be breached copyright ownership compossed to be gotten since that creation first time is publicized (first to publish).

Keywords : Protection, Intellectual Property, Copyright, Registration, Declarative Principle 


\section{A. Pendahuluan}

Kreatifitas dan inovasi teknologi sebagaimana peningkatan ekonomi sangat dibutuhkan bagi pertumbuhan masyarakat dan pengembangan industri. Melalui kreasi dan inovasi teknologi mendatangkan kemakmuran dan pertumbuhan ekonomi bagi kehidupan masyarakat. Sebagai contoh dalam rangka pengembangan teknologi di bidang piranti lunak (software) komputer atau teknologi informasi yang baru diperlukan biaya, waktu dan tenaga kerja yang membutuhkan keahlian tertentu. Di sisi lain kegiatan menggandakan / mengkopi, menggunakan, atau memalsukan kreatifitas dan inovasi yang telah dikembangkan oleh orang lain merupakan sesuatu yang mudah.

Penggunaan atau perbanyakan oleh orang lain tanpa hak menyebabkan dorongan untuk mengembangkan inovasi lain akan menurun atau bahkan hilang dan akibatnya pertumbuhan kreatifitas manusia dan pengembangan industri kreatif dapat terhambat. Dari sudut pandang tersebut, dikembangkan suatu kaidah hukum yang dapat mendorong penelitian dan pengembangan dengan memberikan perlindungan bagi teknologi baru yang tercipta selama waktu tertentu dengan memberikan Hak Eksklusif bagi para pengembang seperti Hak Kekayaan Intelektual.

Perlindungan hukum tersebut diperlukan tidak hanya untuk industri kreatif ataupun teknologi, namunjuga untuk karya sastra (literary works), seni (artistic works) yang pada akhirnya menjadi produk kebudayaan. Begitupun dalam hal perlindungan tanda dagang (brand name), proteksi tidak hanya bagi pemegang merek namun juga para konsumen. Adalah penting untuk melindungi merek yang memiliki fungsi jaminan atau kualitas barang dan memiliki daya tarik bagi konsumen dan juga untuk mempertahankan kredibilitas orang-orang yang berkecimpung dalam produksi atau penjualan, terhadap pihak lain yang tidak berhak. Dengan cara ini, sistem yang terbentuk menyatakan bahwa siapapun tidak dapat menggunakan hasil kreasi intelektual di bidang teknologi, seni dan ilmu pengetahuan, dan sebagainya, dan tanda dagang komersil, tanpa persetujuan dari Pemiliknya (Pencipta (Authors) atau Pemegang Hak (Holders). Pengklasifikasian kepemilikan suatu karya cipta dengan kedudukan Pencipta atau pemegang hak ini semata-mata dalam rangka memberikan perlindungan Hak Moral (Moral Rights) bagi Pencipta (Authors).

Indonesia mengakui dan memberikan penghargaan terhadap karya cipta dan mekanisme perlindungan Haknya dalam Undang-Undang Nomor 19 Tahun 2002 tentang Hak Cipta (UUHC 2002), yang dari segi substansi, terdapat beberapa ketentuan penting yang saling terkait dan bahkan akan dapat menjadi instrumen strategis dalam menunjang proses dan mekanisme penegakan hukum Hak Cipta. Secara khusus UUHC mengatur tentang Pendaftaran Ciptaan ${ }^{1}$. Pendaftaran Ciptaan dapat dilakukan oleh Pemohon baik oleh Pencipta ataupun Pemegang Haknya. Untuk permohonan pendaftaran (application to register) dari Luar Negeri diwajibkan bagi Pemohon Asing (Foreign Applicant) untuk mengajukan permohonan 
Pendaftaran melalui kuasa, kuasa tersebut adalah Konsultan Hak Kekayaan Intelektual Terdaftar pada Direktorat Jenderal Hak Kekayaan Intelektual Kementerian Hukum dan Hak Asasi Manusia (selanjutnya disebut Ditjen HKI).

Dengan dibentuknya sistem Pendaftaran Ciptaan akan berlanjut dengan dibuatnya ketentuan pelaksanaan untuk mekanisme administratif dari proses aplikasi, pemeriksaan, sertifikasi, dan dokumentasi. Diterbitkannya sertifikat berupa Surat Tanda Pendaftaran Ciptaan ini dianggap akan memudahkan pembuktian apabila terjadi sengketa mengenai Hak Cipta baik itu perkara di pengadilan atau di luar pengadilan. Ketentuan Pendaftaran Ciptaan ini tidak seimbang dan mengeyampingkan keberadaan karya-karya Cipta yang tidak didaftarkan, dengan kata lain terhadap ciptaan yang tidak didaftarkan akan lebih sukar dan lebih memakan waktu pembuktian hak ciptanya dari ciptaan yang didaftarkan.

Berdasarkan ketentuan konvensi Internasional dibidang Hak Cipta, termasuk dalam praktek perlindungan atas kreasi terhadap karya seni dan karya sastra tidak mengenal atau tidak mewajibkan adanya Pendaftaran Ciptaan pada instansi tertentu pada suatu negara. Suatu doktrin yang digunakan untuk memproteksi Hak Cipta yaitu suatu ciptaan sudah mendapatkan perlindungan hukum sejak ciptaan tersebut selesai dibuat, dan dapat diketahui, didengar, dilihat oleh pihak lain (first to publish) yang menimbulkan kepemilikan Hak bagi Pencipta ataupun Pemegang Haknya prinsip ini dikenal dengan Asas Deklaratif (Declarative Principal). Artinya suatu Ciptaan tersebut bukan berupa ide-ide atau gagasan namun merupakan ungkapan nyata dari ide-ide atau gagasan tersebut (protected expression of ideas). Dalam arti luas ketentuan kepemilikan suatu
Ciptaan tidak ditentukan oleh adanya registrasi karena suatu karya cipta tersebut sudah mendapatkan perlindungan sejak pertama kali dimumkan, namun secara khusus di Indonesia diselenggarakan mekanisme Pendaftaran Ciptaan.

Maka, berdasarkan problematika terhadap ketidaksesuaianantara PerlindunganCiptaan Hak Cipta yang menganut sistem deklaratif dengan ketentuan Pendaftaran Ciptaan sebagaimana diatur dalam ketentuan Undang-Undang Hak Cipta ini menarik perhatian peneliti untuk mengkaji kembali eksistensi apakah ketentuan Pendaftaran Ciptaan tersebut menyebabkan dilanggarnya asas kepemilikan karya cipta diperoleh sejak ciptaan tersebut pertama kali dipublikasikan (since publication).

\section{B. Permasalahan}

Berdasarkan latar belakang di atas, dirumuskan beberapa permasalahan sebagai berikut:

1. Apakah Undang-Undang Hak Cipta telah sesuai dan efektif dalam kerangka perlindungan dan pembuktian terhadap perkara Hak Cipta?

2. Bagaimana penjabaran prinsip deklaratif dalam memberikan perlindungan hak cipta?

3. Apakah dengan adanya ketentuan Pendaftaran Ciptaan sebagaimana diatur dalam UUHC 2002 menyebabkan dilanggarnya Asas Deklaratif (Declarative Principle)"?

\section{Metode Penelitian}

Tulisan ini menggunakan pendekatan yuridis normatif yang didasarkan pada penelitian kepustakaan dengan mempergunakan data sekunder dalam bidang hukum. Sifat penelitian ini adalah deskriptif analitis, karena melalui tulisan ini diharapkan akan diperoleh gambaran 
secara sistematis dan faktual terkait data hukum yang ada.

\section{Pembahasan}

\section{Ketentuan Pendaftaran Ciptaan}

Dalam rangka pembentukan hukum nasional, pada tanggal 12 April 1982, pemerintah Indonesia memutuskan untuk mencabut Auteurswet (selanjutnya disingkat menjadi A.W) 1912 Staatsblad Nomor 600 Tahun 1912 dan sekaligus mengundangkan UUHC 1982 yang dimuat dalam Lembaran Negara RI Tahun 1982 Nomor 15.

Terdapat dua dasar pertimbangan hukum untuk diundangkannya UUHC, seperti dimuat dalam Mukadimah UUHC 1982, untuk mencabut A.W. 1912, yaitu:

1) Dalam rangka pembangunan di bidang hukum sebagaimana termaksud dalam Garis-garis Besar Haluan Negara (Ketetapan Majelis Permusyawaratan Rakyat Nomor IV/ MPR/1918), serta untuk mendorong dan melindungi penciptaan, penyebarluasan hasil kebudayaan di bidang karya ilmu, seni dan sastra serta mempercepat pertumbuhan kecerdasan kehidupan bangsa dalam wahana Negara Republik Indonesia berdasarkan Pancasila dan Undang-Undang Dasar 1945, maka perlu disusun Undang-undang tentang Hak Cipta;

2) Berdasarkan hal tersebut pada huruf 1 di atas maka pengaturan tentang Hak Cipta berdasarkan Auteurswet 1912 Staatsblad Nomor 600 Tahun 1912 perlu dicabut karena sudah tidak sesuai dengan kebutuhan dan cita-cita hukum Nasional.

Beberapa pengertian umum yang digunakan sebagi dasar untuk mengganti A.W. 1912 dengan UUHC 1982 seperti dimuat dalam Penjelasan atas UUHC 1982, yang perinciannya dalam butirbutir penjelasan kami kutipkan sebagai berikut:

1) Dalam rangka pembangunan di bidang hukum demi mendorong dan melindungi penciptaan, penyebarluasan hasil karya ilmu, seni, dan sastra serta mempercepat pertumbuhan, kecerdasan kehidupan bangsa perlu dibentuk Undang-undang tentang Hak Cipta. Undang-undang tentang Hak Cipta Auteurswet 1912 Staatsblad No. 60 Tahun 1912, perlu diganti karena sudah tidak sesuai dengan kebutuhan dan cita-cita hukum nasional.

2) Dalam undang-undang ini selain dimaksudkan unsur baru mengingat perkembangan teknologi, diletakkan juga unsur kepribadian Indonesia yang mengayomi baik kepentingan individu maupun masyarakat sehingga terdapat keseimbangan yang serasi antara kedua kepentingan termaksud.

Pasal 2 UUHC tahun 1982, ditentukan bahwa:

\footnotetext{
"Hak Cipta adalah Hak Khusus bagi pencipta maupun penerima hak untuk mengumumkan atau memperbanyak ciptaannya maupun memberi ijin untuk itu dengan tidak mengurangi pembatasan-pembatasan menurut peraturan perundang-undangan yang berlaku"
}

Walaupun dalam Pasal 2 UUHC 1982 ini ditentukan hak cipta adalah hak khusus tetapi sesuai dengan jiwa yang terkandung dalam Pasal 33 Undang-Undang Dasar 1945, maka ia mempunyai fungsi sosial dalam arti ia dapat dibatasi untuk kepentingan umum. Hal ini dapat kiranya dilihat:

a. pada kemungkinan membatasi hak cipta demi kepentingan umum/ nasional dengan keharusan memberikan ganti rugi pada penciptanya. 
b. pada penyingkatan waktu berlakunya hak cipta dari 50 (lima puluh) tahun menurut peraturan yang lama menjadi 25 (dua puluh lima) tahun.

c. dengan diberikannya hak cipta kepada negara atas benda budaya nasional.

Secara khusus dalam UUHC 1982 tersebut diatur ketentuan tentang Pendaftaran Ciptaan. Tujuan dari ketentuan Pendaftaran Ciptaan ini dibuat dalam rangka agar negara melalui pemerintah sebagai pelaksananya dapat mengetahui secara positif kepemilikan suatu Ciptaan yang beredar dimasyarakat atau ada dalam wilayah Republik Indonesia, dalam hal ini dapat mengetahui secara formal Pencipta, Pemegang Hak, jenis ciptaan. Dengan adanya pendaftaran ini diharapkan dapat menjadi bukti kepemilikan Hak dan selanjutnya dapat memberikan kepastian hukum baik bagi Pemilik dan Pihak yang berkepentingan.

Disamping Pendaftaran Ciptaan tersebut dapat memberikan kepastian hukum kepemilikan Hak Cipta, pembentukan Sistem Pendaftaran Ciptaan yang konsepnya diatur dalam suatu undang-undang akan memberikan peran strategis bahwa Pemerintah Republik Indonesia sangat concern atas perlindungan Hak Cipta sehingga bersedia menyediakan perangkat tidak saja suatu kaedah hukum namun juga perangkat administratif dalam menata ciptaan yang akan didaftarkan oleh Pemiliknya. Ketentuan tentang Pendaftaran Ciptaan tersebut tidak dicabut atau mengalami perubahan sampai dengan diundangkannya UUHC 2002.

Ketentuan mengenai pendaftaran Hak Cipta, diatur dalam Pasal 35 sampai dengan Pasal 43 UUHC 2002. Kantor Ditjen HKI, menyelenggarakan Pendaftaran Ciptaan dan dicatat dalam Daftar Umum Ciptaan. Daftar Umum Ciptaan tersebut dapat dilihat oleh setiap orang tanpa dikenai biaya. Namun apabila orang ingin memperoleh Daftar Ciptaan untuk dirinya sendiri suatu petikan dari Daftar Umum Ciptaan tersebut dengan dikenai biaya.

Dalam Pasal 35 ayat (4) ditentukan bahwa Pendaftaran Hak Cipta tidak merupakan kewajiban untuk mendapatkan Hak Cipta. Ketentuan dalam Pasal 35 ayat (4) ini merupakan poin penting dalam kerangka perlindungan Hak Cipta. Pendaftaran Ciptaan bukan merupakan suatu keharusan tetapi kerelaan (voluntary) bagi pencipta atau Pemegang Hak Cipta. Dan perlu ditegaskan bahwa timbulnya perlindungan suatu Ciptaan dimulai sejak Ciptaan itu ada atau terwujud (material form) dan bukan karena suatu pendaftaran. Artinya disini bahwa Hak Cipta baik terdaftar maupun tidak terdaftar tetap mendapat perlindungan yang sama oleh Undang-undang.

Peran Kantor Ditjen HKI berfungsi untuk mengadministrasi dan mengelola Pendaftaran Hak Cipta (Pasal 52 UU No. 19 Tahun 2002). Kantor Direktorat Hak Cipta tidak mempunyai wewenang untuk menjustifikasi Hak Cipta tersebut layak didaftar atau tidak, kecuali memang Hak Cipta tersebut bertentangan dengan Undang-Undang, misalnya: gambar marka jalan lalu lintas, tidak dapat didaftar, karena gambar tersebut telah menjadi milik umum.

Sehubungan dengan masalah tersebut, Pasal 36 Undang-Undang Hak Cipta menentukan bahwa, "Pendaftaran Ciptaan dalam Daftar Umum Ciptaan tidak mengandung arti sebagai pengesahan atau isi, arti, maksud, atau bentuk dari Ciptaan yang didaftar. Hal ini berarti bahwa Kantor Ditjen HKI tidak bertanggungjawab atas isi, arti, maksud, atau bentuk dari Ciptaan yang terdaftar. 
Dalam Daftar Umum Ciptaan memuat, antara lain:
a. nama Pencipta dan pemegang Hak Cipta;
b. tanggal penerimaan surat permohonan;
c. tanggal lengkapnya persyaratan; dan
d. nomor pendaftaran Ciptaan.

Dalam Pasal 37 ayat (1) UUHC 2002 menentukan bahwa Pendaftaran Ciptaan dalam Daftar Umum Ciptaan dilakukan atas Permohonan yang diajukan oleh Pencipta atau Pemegang Hak Cipta atau Kuasa. Sebagaimana juga telah ditentukan dalam Undang-Undang Hak kekayaan Intelektual (selanjutnya disingkat HKI) lainnya bahwa yang dimaksud dengan kuasa adalah Konsultan HKI yaitu orang yang memiliki keahlian di bidang $\mathrm{HKI}$ dan secara khusus memberikan jasa mengurus permohonan Hak Cipta, Paten, Merek, Desain Industri serta bidang-bidang Hak Kekayaan lainnya selanjutnya terdaftar sebagai Konsultan HKI di Kantor Ditjen HKI.

Permohonan diajukan kepada Kantor Ditjen HKI dengan surat rangkap 2 (dua) yang ditulis dalam bahasa Indonesia dan disertai contoh Ciptaan atau penggantinya dengan dikenai biaya. Contoh Ciptaan dilampirkan, namun apabila Ciptaan yang dilampirkan tidak dimungkinkan, maka diganti dengan miniatur atau fotonya. Setelah melalui permohonan, maka dalam waktu paling lama 9 (sembilan) bulan sejak diterimanya permohonan Pendaftaran secara lengkap Direktorat Jenderal harus memberikan keputusan diterima atau ditolaknya pendaftaran Hak Cipta.

Pasal 38 UUHC 2002 menentukan bahwa, dalam hal permohonan diajukan oleh lebih dari seorang atau suatu badan hukum yang secara bersama-sama berhak atas suatu Ciptaan, Permohonan tersebut dilampiri salinan resmi atau keterangan tertulis yang membuktikan hak tersebut. Apabila Pendaftaran diterima oleh Kantor Direktorat Hak Cipta, maka Pendaftaran, diumumkan dalam Berita Resmi Ciptaan oleh Direktorat Jenderal. Apabila terdapat Pemindahan atas Pendaftaran Hak Cipta, secara khusus ditentukan dalam Pasal 41 UU No. 19 Tahun 2002, kami kutipkan sebagai berikut:

1) Pemindahan hak atas pendaftaran Ciptaan, yang terdaftar menurut pasal 39 yang terdaftar dalam satu nomor, hanya diperkenankan jika seluruh Ciptaan yang terdaftar itu dipindahkan haknya kepada penerima hak.

2) Pemindahan hak tersebut dicatat dalam Daftar Umum Ciptaan atas permohonan tertulis dari kedua belah pihak atau dari penerima hak dengan dikenai biaya.

3) Pencatatan pemindahan hak tersebut diumumkan dalam Berita Resmi Ciptaan oleh Direktorat Jenderal.

Apabila terdapat perubahan nama dan/atau perubahan alamat orang atau badan hukum yang namanya tercatat dalam Daftar Umum Ciptaan sebagai Pencipta atau Pemegang Hak Cipta, maka atas permintaan tertulis dari Pencipta atau pemegang Hak dicatat dalam Daftar Umum Ciptaan. Perubahan nama dan/atau perubahan alamat tersebut diumumkan dalam Berita Resmi Ciptaan oleh Direktorat Jenderal.

Sebagaimana telah uraikan diatas bahwa pendaftaran Hak Cipta tidak memberikan akibat juridis bahwa Hak Cipta yang telah terdaftar tersebut mempunyai kekuatan hukum sehingga tidak dapat digangu gugat oleh pihak lain. Untuk permasalahan ini Pasal 44 UUHC 2002 memberikan penegasan, bahwa kekuatan hukum dari suatu pendaftaran Ciptaan hapus karena: 


\section{R ${ }^{\text {juknal }}$ HTSVINDING}

Media Pembinaan Hukum Nasional

a. penghapusan atas permohonan orang atau badan hukum yang namanya tercatat sebagai Pencipta atau Pemegang Hak Cipta;

b. lampau waktu;

c. dinyatakan batal oleh putusan pengadilan yang telah memperoleh kekuatan hukum tetap.

Walaupun UUHC 2002 ini diadakan ketentuan dan perangkat mengenai Pendaftaran Ciptaan, namun Pendaftaran Ciptaan ini tidak mutlak atau tidak diwajibkan (non-compulsory), karena tanpa pendaftaranpun hak cipta dilindungi oleh Undang-Undang. Hanya mengenai ciptaan yang tidak didaftarkan akan lebih sukar dan lebih memakan waktu pembuktian hak ciptanya dari ciptaan yang didaftarkan.

Dengan demikian Pendaftaran ciptaan dilakukan secara pasif, artinya bahwa semua permohonan pendaftaran diterima dengan tidak terlalu mengadakan pemeriksaan mengenai validitas aplikasi yang diajukan oleh Pemohon, kecuali jika aplikasi dari Pemohon yang bersangkutan secara nyata bertentangan dengan undang-undang atau tidak termasuk kualifikasi Ciptaan sudah jelas ternyata ada pelanggaran hak cipta. Maka, dalam undangundang ini dianut sistem pendaftaran negatifdeklaratif, seperti pada umumnya dalam hal sengketa, kepada hakim diserahkan kewenangan untuk mengambil keputusan.

Berikut ini adalah mekanisme Pendaftaran Ciptaan sebagaimana ditentukan dalam UUHC 2002 meliputi proses permohonan sampai dengan sertifikasi, sebagai berikut:

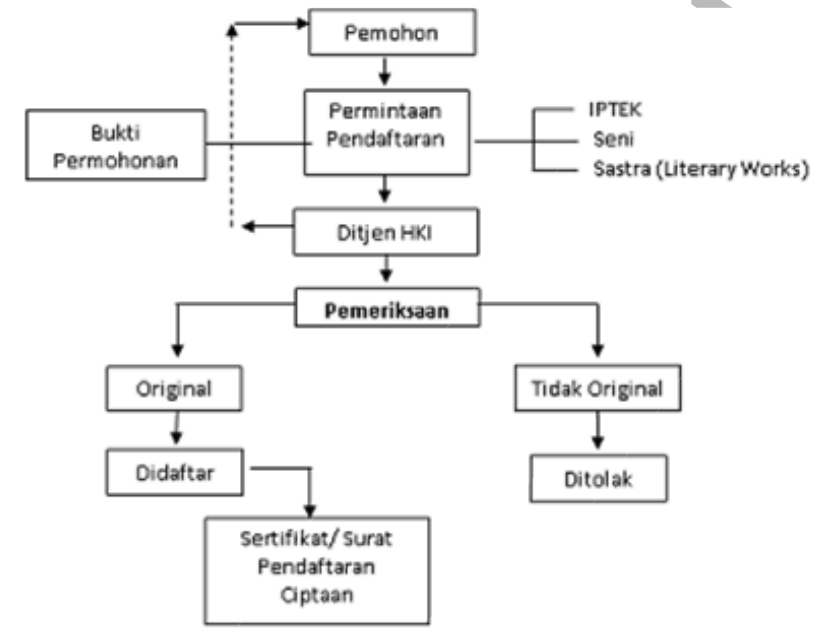

Skema 1: Mekanisme Pendaftaran Ciptaan

Berkenaan permohonan Pendaftaran Ciptaan telah memperoleh sertifikat sebagai surat tanda pendaftaran dari Ditjen HKI, apabila terjadi pelanggaran maka sertifikat sebagai tanda bukti kepemilikan sebagai salah satu bukti untuk diajukan kepada pihak penyidik dan menjadi pertimbangan hakim untuk mengambil keputusan. Berikut ini kami uraikan tabel proses gugatan/ tuntutan apabila terjadi pelanggaran Hak Cipta.

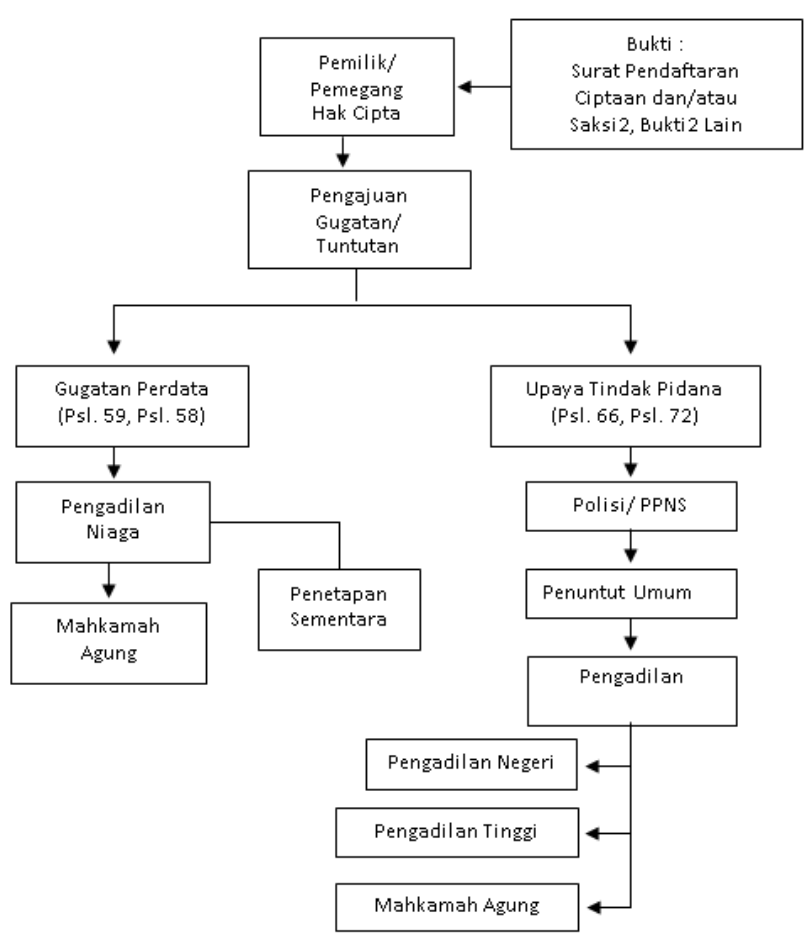

Skema 2: Proses Gugatan/Tuntutan Pelanggaran Hak Cipta 


\section{Prinsip Deklaratif dalam Perlindungan Hak Cipta}

Prinsip dalam membedakan perlindungan Hak Cipta dengan perlindungan Hak atas Kekayaan Intelektual lainnya adalah bahwa Hak Cipta melindungi karya sastra (literary works) dan karya seni (artistic works) dengan segala bentuk perkembangannya di dunia ini. Sebagai contoh karya sastra dapat berupa buku pelajaran, teks lagu, tulisan, dan lain-lain, sedangkan karya seni dapat berupa lagu/ musik, tarian, lukisan, dan lain-lain.

Hak Cipta adalah bagian dari sekumpulan hak yang dinamakan Hak Kekayaan Intelektual (HKI) yang pengaturannya terdapat dalam ilmu hukum dan dinamakan Hukum HKI. Hukum HKI ini, meliputi suatu bidang hukum yang membidangi hak-hak yuridis dari karya-karya atau ciptaan-ciptaan hasil olah pikir manusia bertautan dengan kepentingan-kepentingan yang bersifat ekonomi dan moral. Bidang yang dicakup dalam hak-hak atas kekayaan intelektual sangat luas, karena termasuk didalamnya semua kekayaan intelektual yang dapat terdiri dari: ciptaan sastra, seni, dan ilmu pengetahuan.

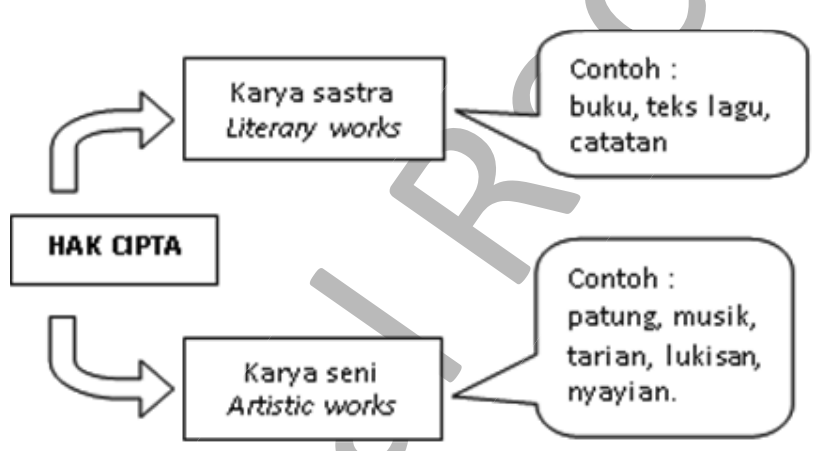

Skema 3: Pembagian Umum Hak Cipta
Menurut WIPO ${ }^{2}$ dan oleh praktek negaranegara, HKI dikelompokkan secara tradisional kedalam dua kelompok kekayaan intelektual (juga bandingkan dengan tabel objek Hak Cipta sebagai bagian dari perlindungan Hak kekayaan Intelektual (HKI):

1) Kekayaan industrial (industrial property) terdiri dari:

a. Invensi teknologi (paten);

b. merek;

c. desain industri;

d. rahasia dagang;

e. indikasi geografis.

2) Hak cipta (copy rights) dan Hak-hak yang Berkaitan (Neighboring Rights) yang terdiri antara lain:

a. karya-karya tulis;

b. karya musik;

c. rekaman suara;

d. pertunjukan pemusik, aktor dan penyanyi.

Pada umumnya, hukum kekayaan intelektual bertujuan untuk melindungi para pencipta dan produser barang dan jasa intelektual lainnya melalui pemberian hak tertentu secara terbatas untuk mengontrol penggunaan yang dilakukan produser tersebut. Hak itu tidak berlaku pada barang-barang fisik dimana kreasi dapat diwujudkan tetapi sebagai pengganti kreasi intelektual itu saja.

Pengertian tentang intellectual property bukan merupakan pengertian baku, dalam hal ini Pendapat WIPO dalam General Information, sebagai berikut ${ }^{3}$ : 
No international treaty defines these concepts, and the various countries diffe form each other on several important points. It is not posibble, therefore, to give universally accepted definitions of the various forms of international property.

Walaupun suatu definisi tentang kekayaan intelektual (kekayaan industrial dan hak cipta) yang diterima secara umum/ universal tidak ada (no single generic term) ${ }^{4}$. Namun, untuk dipakai sebagaipedomandalammelakukan pembahasan selanjutnya ada baiknya di sini dikemukakan beberapa definisi yang dikemukakan beberapa penulis, ${ }^{5}$ bahwa untuk mencakup dalam suatu definisi yang memuaskan semua yang tergolong kekayaan intelektual adalah tidak dimungkinkan, dan pendapatnya, sebagai berikut:

"There is no single generic term that satisfactorily covers them all, Traditionally, the term "intellectual property" was used to refer to the rights conferred by the grant of a copyright in literary, artistic and musical works."

Secara tradisional kekayaan intelektual dibagi menjadi dua cabang: "kekayaan industri" dan "hak cipta". "Kekayaan industri" mencakup perlindungan invensi melalui paten, perlindungan kepentingan komersial tertentu melalui undang-undang merek dan undangundang tentang nama dagang, dan undangundang tentang perlindungan desain industri. Disamping itu, kekayaan industri meliputi pengendalian persaingan yang tidak wajar. "Hak cipta" memberikan hak-hak tertentu kepada para pengarang atau pencipta karya intelektual lainnya (sastra, musik dan seni) untuk memberikan wewenang atau melarang untuk menggunakan karya tersebut selama waktu tertentu. Secara luas, hak cipta mencakup ketentuan-ketentuan tentang perlindungan hak cipta menurut pengertian kata yang tepat dan juga perlindungan terhadap apa yang biasanya disebut "hak-hak terkait", sehingga eksklusif sifatnya.

Perjanjian TRIP's tidak mendefinisikan kekayaan intelektual, tetapi Pasal 1. 2 - nya menyebutkan bahwa kekayaan intelektual terdiri dari:

- hak cipta dan hak-hak yang berkaitan dengan hak cipta (seperti hak dari artis pertunjukan, produser rekaman suara dan organisasi penyiaran);

- merek;

- indikasi geografis;

- desain industri;

- paten;

- desain rangkaian listrik terpadu;

- rahasia dagang dan data mengenai test (test data);

- varietas tanaman baru.

Jadi kekayaan intelektual berhubungan dengan permohonan perlindungan atas gagasangagasan dan informasi yang mempunyai nilai komersial. Kekayaan intelektual merupakan kekayaan pribadi yang bisa dimiliki dan dialihkan kepada orang lain sebagaimana halnya jenisjenis kekayaan lainnya, termasuk dijual dan dilisensikan.

Konsepsi yang mendasar dalam rezim hukum hak cipta adalah bahwa hak cipta tidak melindungi ide-ide, informasi atau fakta-fakta, tetapi lebih melindungi bentuk dari pengung-

W.R. Cornish, Intellectual Property, Patent, Copyright, Trade Marks and Allied Rights, (Sweet \& Maxwell, $2^{\text {nd }}$ Edition, 1989),, hlm. 3.

5 Stainforth Ricketson and M. Richardson, Intellectual Property: Cases, Materials and Commentary, (Butterwoths, $2^{\text {nd }}$ edition, 1998), hlm. 3. 
kapan ide-ide, informasiatau fakta-fakta tersebut (expression of ideas). Hal mana juga diatur ditentukan oleh negara-negara anggota WIPO, Australia misalnya, Hak cipta didefinisikan: ${ }^{6}$

"Copyright is form of intellectual property protection for a variaty of creative works. It is not ideas but their expression which are subject to copyright."

Dengan demikian dapat dikatakan bahwa Hak cipta adalah ada (exist) dalam bentuk nyata (real), dan bukan ide-ide itu sendiri. Maka Hak Cipta tidak melindungi ide-ide atau informasi sampai ide atau informasi tersebut dituangkan dalam bentuk yang dapat dihitung dalam bentuk materi, dan dapat diproduksi ulang.

\section{Keterkaitan Pendaftaran Ciptaan de- ngan Prinsip Deklaratif}

Munculnya suatu karya telah begitu melibatkan tenaga, waktu, dan biaya, apabila dikonversikan ke dalam angka-angka akan menunjukkan nilai karya yang memiliki manfaat atau nilai ekonomi pada suatu karya cipta. Selanjutnya timbullah kemudian konsepsi mengenai kekayaan, yang pada gilirannya, tumbuh konsepsi hukum mengenai hak dan kebutuhan untuk melindunginya. Pengembangan konsepsi hukum ini, bila dilihat dari segi usaha untuk mendorong tumbuhnya sikap dan budaya menghormati atau menghargai jerih payah atau hasil karya orang lain, memiliki arti yang penting. Apabila kalau hal ini ditinjau dari kebutuhan negara untuk mewujudkan tatanan kehidupan ekonomi yang tetap memberikan penghormatan terhadap hak-hak perseorangan secara seimbang dengan kepentingan masyarakat bangsanya.

Menurut Megan Richarson, keuntungan ekonomi (economic benefit) dari Hak Cipta, dengan mempertimbangkan beberapa hal sebagai berikut: ${ }^{7}$

a. wheather material incentive provided by copyright are relevant to the innovative process behind copyright works and others subject matter;

b. wheather, given that we import more copyright material than we export, Australia is a net loser from a copyright system that rewards innovation;

c. wheather the cost associated with the granting proprietary rights over information outweigh the benefit of copyright.

Manfaat lain, umumnya dialami oleh pelaku seni (artist) melalui perlindungan Hak Cipta, sangat memberikan keuntungan ekonomis bagi pencipta dan pemegang Hak Cipta, dimana pendapat mereka sangat tergantung pada pasar: ${ }^{8}$

Almost all artist who have done anything approaching first-rate work have been thoroughly bourgeois people - leading quiet, unostentatious lives, indifferent to the world's praise or blame, and far to much interest in their job to spend their time kicking over the traces.

Dasar pemikiran diberikannya kepada seorang atau individu untuk perlindungan hukum terhadap "ciptaan" bermula dari teori yang tidak lepas dari dominasi pemikiran Mazhab atau Dokrin Hukum Alam yang menekankan pada faktor manusia dan pengunaan akal seperti

CAL (Copyright Agency Ltd), Copyright Information Sheet, (Sydney: Copyright Agency Ltd, $2^{\text {nd }}$ Edition, 2000), hlm. 12.

Megan Richardson, etc., The Benefits and Costs of Copyrights: an Economic Perspective, (Discussion Papers for The Centre for Copyright Studies Ltd., June 2000), hlm. 7.

$8 \quad$ CLRC. Australia, Copyright Reform: Consideration of Rationales, Interest and Objectives, (1996), hlm. 18., juga lihat Office Regulation Review., An Economic Analysis of Copyright Reform, (1995), hlm. 4. 
yang dikenal dalam Sistem Hukum Sipil (Civil Law System) yang merupakan sistem hukum umum yang dipakai di Indonesia. ${ }^{9}$

Pengaruh Mazhab Hukum Alam dalam Civil Law System ini terhadap seorang individu yang menciptakan pelbagai ciptaan yang kemudian memperoleh perlindungan hukum atas ciptaan yang merupakan kekayaan intelektual. Perkembangan ini juga dikemukakan oleh $\mathrm{S}$. Stewart dengan: ${ }^{10}$

Countries that follow the civil law tradition, however, regard authors' rights as natural human rights, or part of one's right of personalit. As apart of this tradition, in addition to the protection of the author's economic rights, the protection of the author's "moral right" is an essential part of the system.

Stewart mengajukan sebuah summary Prinsip-prinsip Hak Cipta Internasional dan sinopsis Hukum Hak Cipta di beberapa negara. Stewart juga telah mengidentifikasi Hukum Hak Cipta negara-negara penganut Sosialis (Socialist Copyrights Law) sebagai satu kategori. Menurutnya bagaimanapun juga, sejak berakhirnya Uni Soviet (USSR), banyak negaranegara bekas sosialis telah bergerak dengan perundang-undangan Hak Cipta Modern (moderncopyrights legis/ation). Misalnya Hukum Hak Cipta dari Republik Rakyat China dan Rusia menganut model civil law system.

Melalui pengakuan secara universal ini, sudah tidak diragukan lagi bahwa suatu ciptaan mempunyai manfaat bagi kehidupan manusia (life worthy) dan mempunyai nilai ekonomi sehingga menimbulkan adanya tiga macam konsepsi: ${ }^{11}$ (1) Konsepsi Kekayaan; (2) Konsepsi Hak; dan (3) Konsepsi Perlindungan Hukum.
Bertolak dari hasil uraian tentang berbagai pendapat di atas, situasi pada masa kini sangat kondusif bagi penciptaan suatu kepastian hukum dan pengayoman atau perlindungan hukum yang berintikan keadilan dan kebenaran, sehingga pembangunan hukum pada umumnya, dan perlindungan HKI pada khususnya perlu segera ditingkatkan lebih cepat menuju terwujudnya sistem hukum nasional yang menyeluruh dan terpadu.

Hal yang paling mendasar bagi perlindungan hak atas kekayaan intelektual adalah bahwa seseorang yang telah mencurahkan usahanya untuk menciptakan/ menemukan sesuatu selanjutnya mempunyai hak alamiah/ dasar untuk memiliki dan mengontrol apa-apa yang telah diciptakannya.

Menurut Pasal 27 (2) dari Deklarasi Universal Hak Asasi Manusia (Universal Declaration of Human Rights), menyebutkan bahwa:

"Everyone has the right to the protect of the moral and material interest resulting form any scientific, literary, or artistic production of which he/she is the author".

"Setiap orang mempunyai hak untuk menlindungi kepentingan moral dan material yang berasal dari ilmu pengetahuan, sastra atau hasil seni yang mana dia merupakan penciptanya".

Secara substantif pengertian HKI dapat di deskripsikan sebagai "Hak atas kekayaan yang timbul atau lahir karena kemampuan intelektual manusia". Penggambaran di atas pada dasarnya memberikan kejelasan bahwa HKI memang menjadikan karya-karya yang timbul atau lahir karena kemampuan intelektual manusia sebagai inti dan objek pengaturannya. Demikian juga dalam Hak Cipta yang merupakan bagian dari

\footnotetext{
9 Satjipto Rahardjo, Ilmu Hukum Cet. Pertama, (Bandung: Alumni, 1972), hlm. 292.

10 S. Stewart., International Copyright and Neighboring Right, $2^{\text {nd }}$ Edition, (1989), hlm. 33.

11 Eddy Damian, Op.Cit., hlm. 18.
} 
$\mathrm{HKI}$, pemahaman mengenai hak atas kekayaan yang timbul atau lahir karena kemampuan intelektual tersebut, telah berwujud karya cipta. ${ }^{12}$

Dalam kerangka permasalan inilah kehadiran Undang-undang Hak Cipta perlu memperoleh perhatian sewajarnya. Seperti terurai sebelumnya, yang baru bagi bangsa Indonesia pada dasarnya hanyalah pengenalan konsepsi tentang pengaturan secara lugas dalam sistem hukum nasional. Dalam ilmu hukum, Hak Cipta seperti halnya hak-hak lainnya yang dikenal dalam HKI digolongkan sebagai hak milik perorangan yang tidak berwujud. Hak ini bersifat khusus, karena hak tersebut hanya diberikan kepada pemilik atau pemegang hak yang bersangkutan untuk dalam waktu tertentu memperoleh perlindungan hukum guna mengumumkan, memperbanyak, mengedarkan, dan lain-lain hasil karya ciptanya, atau memberi ijin kepada orang lain untuk melaksanakannya. Hak Cipta sering pula dikatakan eksklusif, karena mengenyampingkan orang lain untuk mengumumkan, memperbanyak, atau mengedarkan dan lain-lain kecuali atas ijin pemilik atau pemegang hak yang bersangkutan. Ciriciri seperti itu pula yang kemudian sering mengundang semacam kritik, bahwa Hak Cipta berkembang dari paham "individualisme", bertentangan dengan paham kekeluargaan dan kegotong-royongan bangsa Indonesia. ${ }^{13}$

Lebih jauh, pembangunan ekonomi nasional harus berlandasan UUD 1945 dan Pancasila sebagai moral kehidupan bangsa. Dengan berlandasan pada Pasal 33 UUD 1945 yang menyebutkan bahwa Perekonomian disusun berdasarkan asas kekeluargaan diharapkan dapat tercipta suatu keseimbangan dalam kegiatan usaha besar, menengah dan kecil dalam pola kemitraan usaha. Dalam sistem ekonomi yang berasaskan kebersamaan dan kekeluargaan tersebut diharapkan semua pihak dapat bersaing secara kekeluargaan, saling membina agar bersama-sama dapat maju dalam mengembangkan perekonomian nasional yang efisien. ${ }^{14}$

Untuk dapat mewujudkan pembangunan ekonomi yang diciptakan tersebut, diperlukan adanya perlindungan hukum bagi hak ekonomi individu. Di Indonesia, Pasal 27 ayat (1) UUD 1945 berbunyi:

(1) "Segala warga negara bersamaan kedudukannya di dalam hukum dan pemerintah dan wajib menjujung hukum dan pemerintahan itu dengan tidak ada kecuali"

(2) "Tiap-tiap warga negara berhak atas pekerjaan dan penghidupan yang layak bagi kemanusiaan"

Berdasarkan uraian di atas, selain diatur persamaan hak-hak dasar warga negara, juga tersirat makna bahwa negara berkewajiban melindungi warga negaranya yang lemah dari segi ekonomi Hal ini dimaksudkan agar dalam proses berekonomi, secara bertahap dapat bersaing secara wajar dengan pengusaha atau negara lainnya yang telah lebih dahulu mampu berkompetisi, berdasarkan prinsip demokrasi ekonomi. ${ }^{15}$

12 Suyud Margono, Hukum dan Perlindungan Hak Cipta, (Jakarta: Novindo Pustaka Mandiri, Cet. Pertama, 2003), hlm. 4 - 5 .

13 Bambang Kesowo., Op.Cit., hlm. 8.

14 Djuhaedah Hasan, Lembaga Jaminan Kebendaan bagi Tanah dan Benda Lain yang melekat pada Tanah dalam Konsepsi Penerapan Asas Pemisahan Horizontal, (Bandung: PT. Citra AdityaBakti, Cet. Pertama), hlm. 12.

15 Sri Edi Swasono, Membangun Sistem Ekonomi dan Demokrasi ekonomi, (Jakarta: UI-Press, Cet. Kedua, 1985), hlm. 99. 
Salah satu bagian penting dari pembangunan ekonomi adalah pembangunan di bidang industri, Pembangunan industri yang berlangsung di Indonesia diarahkan untuk menciptakan kemandirian Perekonomian nasional dengan meningkatkan kesejahteraan rakyat melalui peran serta aktif Masyarakat yang didukung oleh produktifitas masyarakat yang sehat dalam menghasilkan barang dan jasa. Diharapkan dalam pembangunan industri yang berlangsung dapat meningkatkan penguasaan pasar dalam negri dan memperluas pasar luar negeri. ${ }^{16}$

Mochtar Kusumaatmadja menyatakan bahwa hukum merupakan sarana pembaharuan masyarakat. Hal ini didasarkan pada suatu anggapan bahwa adanya keteraturan atau ketertiban itu merupakan suatu hal yang diinginkan, bahkan dipandang perlu. Lebih jauh lagi anggapan lain yang terkandung dalam konsepsi hukum sebagai sarana pembaharuan masyarakat adalah hukum dalam arti kaidah atau peraturan hukum memang dapat berfungsi sebagai alat (pengatur) atau sarana pembangunan dalam arti penyalur arah kegiatan manusia ke arah yang dikehendaki oleh pembangunan atau pembaharuan. ${ }^{17}$

Roscue Pound berpendapat "Law as a toll of social engineering"18 bahwa hukum sebagai sarana rekayasa sosial, hukum tidak pasif, tetapi harus mampu digunakan untuk mengubah suatu keadaan dan kondisi tertentu ke arah yang dituju sesuai dengan kemauan masyrakatnya. ${ }^{19}$ Dengan demikian, hukum menciptakan keadaan yang relatif sangat baru, tidak sekadar mengatur keadaan yang telah berjalan. Komar Kantatmadja menyatakan bahwa yang dimaksudkan dengan hukum sebagai sarana pembaharuan adalah sebagai berikut: ${ }^{20}$

"Hukum harus mampu memenuhi kebutuhan sesuai dengan tingkat kemajuan serta tahapan pembangunan di segala bidang sehingga dapat diciptakan ketertiban dan Kepastian hukum untuk menjamin serta memperlancar pelaksanaan pembangunan".

Sumantoro menyatakan bahwa hukum dapat berfungsi sebagai agent of modernization and instrument of social engineering. ${ }^{21}$ Dengan demikian, pembangunan hukum juga dapat berjalan di depan bersama pembangunan ekonomi dalam upaya mencapai masyarakat yang adil dan makmur. Mendukung pendapat di atas, Sunaryati Hartono menyatakan bahwa makna dari pembangunan hukum meliputi empat hal sebagai berikut: ${ }^{22}$

1. menyempurnakan (membuat sesuatu yang lebih baik);

2. mengubah agar menjadi lebih baik dan modern;

3. mengadakan sesuatu yang sebelumnya belum ada, atau;

4. meniadakan sesuatu yang terdapat dalam sistem lama karena tidak diperlukan dan tidak cocok dengan sistem baru.

\footnotetext{
16 Ranti Fauza Mayana, Perlindungan Desain Industri di Indonesia dalam Era Perdagangan Bebas, (Jakarta: PT. Gramedia Widiasarana Indonesia (Grasindo), 2004), hlm. 27.

17 Mochtar Kusumaatmadja, Hukum, Masyarakat dan Pembinaan Hukum Nasional, (Bandung: Bina Cipta, Cet. Pertama, 1976), hlm. 4.

18 Lili Rasjidi, Dasar-Dasar Filsafat Hukum, (Bandung: Citra AdityaBakti, Cet. Kedua, 1996), hlm. 83.

19 W. Friedman, Legal Theory, (London: Steven \& Sons Limited, 1960), hlm. 293-296.

20 Komar Kantaatmadja, Perandan Fungsi ProfesiHukum Dalam Undang-UndangPerpajakan, makalah, dalam Seminar Nasional Hukum Pajak, IMNO-UNPAD, Bandung, Juli 1985.

21 Sumantoro, Hukum Ekonomi, (Jakarta: UI Press, Cet. Kedua, 1986), hlm. 180.

22 Sunaryati Hartono, "Sejarah Pekembangan Hukum Nasional Indonesia Menuju Sistem Hukum Nasional", Makalah, 1991.
} 
Bertolak dari pemahaman mengenai segala hal terdahulu dan dalam kerangka menghindari suatu pelanggaran dalam Hak Cipta, ramburambu pengaturannya secara seksama telah diformulasikan dalam perundang-undangan, $\mathrm{Di}$ Indonesia sejak tahun 1970-an upaya pengaturan Hak Cipta ini dimulai dan kemudian memberikan hasil berupa UUHC 1982. Pada tanggal 12 April 1982, oleh pemerintah Indonesia memutuskan untuk mencabut Auteurs Wet,Staatsblad Nomor 600 Tahun 1912 dan sekaligus mengundangkan Undang-undang RI Nomor 6 Tahun 1982 tentang Hak Cipta yang dimuat dalam Lembaran Negara RI Tahun 1982 Nomor 15 Undang-Undang No. 7 Tahun 1987 tentang Perubahan Undang-Undang No. 6 Tahun 1982 tentang Hak Cipta ditujukan karena Pertumbuhan dan perkembangan ilmu pengetahuan, seni, dan sastra. Selanjutnya, sistem Hukum Hak Cipta juga mengalami perubahan yang signifikan dari sudut substansi, hal ini tidak hanya dialami oleh Indonesia namun juga oleh negara-negara anggota yang menandatanggani perjanjian WTO (World Trade Organization).

Indonesia merupakan salah satu dari 110 negara yang menandatangani hasil akhir Putaran Uruguay. Selanjutnya Indonesia dengan resmi telah mengesahkan keikutsertaan dan menerima Convention Establishing the World Trade Organization dengan Undang-Undang No. 7 Tahun 1994. Sebagai konsekuensi dari keanggotaan Indonesia di WTO, Indonesia antara lain harus menyelaraskan segala pranata peraturan perundang-undangan di bidang HaKI dengan norma dan standar yang disepakati. Sesuai dengan Pasal 65 Persetujuan TRIPs (Trade Related Aspect on Intellectual Property Rights and Counterfeit Goods Agreement), Indonesia sebagai negara berkembang mendapatkan tenggang waktu sampai 1 Januari 2002.
Pasca penandatangganan TRIPS Agreement tersebut, memberikan konsekuensi produk Hukum Hak Cipta di Indonesia untuk diadakan perubahan dalam rangka memenuhi standarisasi pemberlakukan TRIPS Agreement tersebut. Perubahan Undang-Undang dilakukan yaitu dengan diundangkannya Undang-Undang No. 12 Tahun 1997 tentang perubahan UndangUndang No. 6 Tahun 1982 sebagaimana diubah dengan Undang-Undang No. 7 tahun 1987 dan perubahan terakhir kali dengan diundangkannya UU No. 19 tahun 2002 tentang Hak Cipta yang dianggap telah memenuhi seluruh ketentuan dalam TRIPS Agreement termasuk beberapa Current Issues internasional di bidang Hak Cipta Tradisional khususnya perlindungan atas expression of folklore.

Persetujuan TRIPs Agreement, menimbulkan kebutuhan untuk menghadirkan beberapa ketentuan internasional bidang Hak Cipta dengan beberapa ciri pokok pengaturannya masing-masing dan unsur-unsur yang dimaksud dalam TRIPs Agreement. Terhadap hukum nasional yang berlaku bagi masing-masing negara anggota penandatangan, bentuk pemberlakuan ketentuan-ketentuan Hak Cipta dalam skala internasional antara lain berupa:

(1) memberlakukan Konvensi Bern 1971 yang belum berlaku bagi Indonesia;

(2) mencabut ketentuan-ketentuan Hak Cipta yang tidak sesuai dan menggantinya dengan yang sesuai dengan ketentuan-ketentuan Persetujuan TRIPs;

(3) menetapkan penambahan ciptaan-ciptaan yang diatur dalam Persetujuan TRIPs yang dinamakan Hak-hak yang Berkaitan dengan Hak Cipta.

Konvensi Bern, dikatakan sebagai sebagai dasar dan acuan pengaturan hukum Hak Cipta bagi Negara-negara di dunia atau disebut 
dengan law making treaty, sebagaimana kami kutipkan bahwa Negara-negara anggota WTO harus memenuhi seluruh ketentuan Konvensi Bern dalam produk Hukum Hak Cipta masingmasing, yaitu dalam bagian II Section 1: Copyright and Related Rights, TRIPs Agreement, Pasal 9 berkaitan dengan Berne Convention:

"Members shall comply with Article 1 through 21 of the Berne Convention (1971) and the Appendix thereto. However, Members shall not have rights or obligations under this Agreement in respect of the rights conferred under Article 6bis of that Convention or of the rights derived therefrom".

Konvensi Bern 1886, pada garis besarnya memuat prinsip dasar mengenai sekumpulan ketentuan yang mengatur standar minimum perlindungan hukum (minimum standart of protection) yang diberikan kepada pencipta dan sekumpulan ketentuan yang berlaku khusus bagi negara-negara anggota WTO. Keikutsertaan suatu negara sebagai anggota Konvensi Bern memuat tiga prinsip dasar yang menimbulkan kewajiban negara peserta untuk menerapkan dalam perundang-undangan nasionalnya di bidang hak cipta, yaitu:

\section{(1) Prinsip national treatment:}

Ciptaan yang berasal dari salah satu negara peserta perjanjian (yaitu ciptaan seorang warganegara dari negara peserta perjanjian, atau suatu ciptaan yang pertama kali diterbitkan di salah satu negara peserta perjanjian) harus mendapat perlindungan hukum Hak Cipta yang sama seperti diperoleh ciptaan seorang pencipta warga negara sendiri.

\section{(2) Prinsip automatic protection:}

Pemberian perlindungan hukum harus diberikan secara langsung tanpa harus memenuhi syarat apapun (no conditional upon compliance with any formality).

\section{(3) Prinsip independence of protection:}

Bentuk perlindungan hukum Hak Cipta diberikan tanpa harus bergantung kepada pengaturan perlindungan hukum negara asal pencipta.

Kutipan Pasal 5 ayat (1) dan (2) Konvensi Bern sebagai berikut:

(1) Authors shall enjoy, in respect of works for which they are protected under this Convention, in countries of the Union others than the country of origin, the rights which their respective laws do now or may hereafter grant to their nationals, as well as the rights specially granted by this Convention.

(2) The enjoyment and the exercise of this rights shall not be subject to any formality; such enjoyment and such exercise shall be independent of the existence of protection in the country of origin of the works. Consequently, apart from the provision of this Convention, the extent of protection, as well as the means of redness afforded to the authors to protect his rights shall be governed exclusively by the laws of the country where protection is claimed.

Dengan mengacu pada keberlakukan ketentuan konvensi internasional di bidang Hak Cipta khususnya Konvensi Bern, setiap ciptaan sudah mendapatkan perlindungan secara otomatis (automatic protection) sejak Ciptaan menjadi nyata (real expression), perlindungannya diberikan langsung tanpa bergantung dari Negara asal pencipta (direct and independent protection), dan pemberlakukan ketentuan ini berlaku sama bagi seluruh negara-negara yang telah meratifikasi Konvensi Bern termasuk negara-negara anggota WTO yang juga menandatanggani TRIPS Agreement. Dengan demikian tidak diperlukan intervensi negara termasuk suatu negara membentuk suatu sistem registrasi suatu karya cipta yang 
selanjutnya menjadi bukti atau formalitas suatu kepemilikan ciptaan.

Ketentuan prinsip deklaratif dalam Konvensi internasional dibidang Hak Cipta ini sesuai dengan doktrin dan asas hukum perlindungan ciptaan. Asas yang mendasar dalam rezim hukum hak cipta adalah bahwa hak cipta tidak melindungi ide-ide, informasi atau faktafakta, tetapi lebih melindungi bentuk dari pengungkapan ide-ide, informasi atau faktafakta tersebut (protectedexpression of ideas). Hal mana juga diatur ditentukan oleh negaranegara anggota WIPO, Australia misalnya, Hak cipta didefinisikan:23 "Copyright is form of intellectual property protection for a variaty of creative works. It is not ideas but their expression which are subject to copyright".

Dapat dikatakan bahwa Hak cipta adalah ada (exist) dalam bentuk nyata (real), dan bukan ideide itu sendiri. Maka Hak Cipta tidak melindungi ide-ide atau informasi sampai ide atau informasi tersebut dituangkan dalam bentuk yang dapat dihitung dalam bentuk materi (material form), dan dapat dipublikasi (publication) ataupun diproduksi ulang (reproduction) yang kemudian berkembang menjadi konsep kekayaan yang memberikan manfaat ekonomi bagi Pencipta atau Pemegang Hak-nya.

Hak Cipta sebagai bagian dari perlindungan Kekayaan intelektual memilki hak-hak yang ditimbulkan atas kekayaan yang dimilikinya, dalam hal ini pemilik Hak Cipta dapat melakukan perbuatan-perbuatan hukum tertentu atas kekayaan yang dimilikinya. Hak-hak yang timbul dari suatu Ciptaan dalam Hak Cipta oleh Hukum diberikan secara bersamaan dengan keistimewaan-keistimewaan tertentu, yaitu Hak untuk mengeksploitasi ciptaannya. Konsepsi kekayaan dalam Hak Cipta yang bersifat eksklusif ini juga disampaikan menurut Bruce A. Lehman, berpendapat: ${ }^{24}$

"Ownership of a copyright, or any of the exclusive rights under a copyright, is distinct from ownership of any material object in which the work is embodied. Transfer of ownership of any material object, including the copy or phonorecord in which the work is first fixed, does not of itself convey any rights in the copyrighted work embodied in the object; nor, in the absence of an agreement, does transfer of ownership of a copyright or of any exclusive rights under a copyright convey property rights in any material object".

Konsepsi kepemilikan (possesion), kekayaan atau hak-hak kekayaan lain yang melekat kepada atau terkait dengan mengkopi dari karya cipta (copyrighted work), termasuk hak untuk mendapatkan akses melalui media network komputer, tidak seorangpun dapat menguasai dan menjalankan hak-hak eksklusif dari pemilik Hak Cipta (copyright owner), (misal hak untuk mengumumkan kepada publik (to perform it publicly) atau hak untuk mereproduksi).

Kepemilikan HakCipta terkait dengan hak-hak yang melekat atau dimiliki pemegang Hak Cipta. Pada Umumnya Hukum Hak Cipta memberikan beberapa hak yang dikenal dengan Hak Eksklusif (a number exclusive rights). Berikut ini kami kutipkan beberapa hak eksklusif terhadap suatu karya Cipta, yaitu: ${ }^{25}$

\section{CAL (Copyright Agency Ltd), Op.Cit.,hlm. 12.}

24 Bruce A. Lehman, Intellectual Property and The National Infrastructure: The Report of The Working Group on Intellectual Property Rights, Information Infrastructure Task Force, (Washington D.C: USPTO, September 1995), hlm. 137.

25 Attorney General's, Department Copyright Law Australia, Short Guide Copyrights Information, (Attorney General's Department Copyright Law in Australia, January 2000). 
"These exclusive rights vary according to the different types of works and other subjectmatter protected by copyright.The owner of copyright in a literary, dramatic or musical work has the following exclusive rights:

1. to reproduce the work in a material form (which includes making a sound recording or film of the work or including the work in a database);

2. to publish the work (that is, to make copies of the work available to the public for the first time);

3. to perform the work in public;

4. to broadcast the work;

5. to make an adaptation of the work (which includes an arrangement of a musical work and a dramatisation or translation of a literary work);

6. cable television), and;

7. in the case of computer programs, and works recorded in sound recordings, to commercially rent the sound recording or computer program".

Hak Pencipta dan Pemegang Hak dalam ruang lingkup karya seni memiliki beberapa hak eksklusif sebagai berikut:

- to reproduce the work in a material form (which includes reproducing a twodimensional work in a three-dimensional form and vice versa);

- to public the works;

- to include the work in a television broadcasts, and;

- to transmit a television program which includes that work to subscribers to a television services.

Bagi Indonesia, dengan adanya ketentuan Pendaftaran Ciptaan ini, memberikan konsekuensi Kantor Ditjen HKI memiliki kewenangan berdasarkan Undang-Undang untuk mengelola Pendaftaran Ciptaan tersebut, termasuk administrasi yaitu Ditjen HKI bertindak menerima, memeriksa dan menerbitkannya dalam Daftar
Umum Ciptaan. Konsekuensi dari ketentuan tentang Pendaftaran Ciptaan ini Kantor Ditjen HKI bertindak selaku Pemeriksa dan menentukan suatu karya cipta tersebut layak atau tidak layak untuk didaftar. Padahal dalam Pendaftaran Ciptaan tidak terdapat pemeriksaan Substantif (Substative Examination), hal ini akan menjadi masalah khususnya tentang objektifitas dari pemeriksa.

Ketentuan Pendaftaran Ciptaan belum cukup efektif dalam memberikan perlindungan Hak Cipta, ketentuan ini hanya memberikan kesan bahwa Pemerintah Negara Republik Indonesia secara aktif memberikan proteksi bagi perlindungan Hak Cipta. Ketentuan Pendaftaran Ciptaan ini terdapat ketidaksesuaian karena perlindungan Hak Cipta itu seharusnya sejak Ciptaan tersebut selesai dibuat, artinya tanpa pendaftaran pun suatu karya Cipta diakui dan mendapatkan perlindungan. Dengan demikian ketentuan Pendaftaran Ciptaan dalam UndangUndang Hak Cipta tidak mutlak atau tidak diwajibkan (non-compulsary). Dengan kata lain, Pendaftaran ciptaan dilakukan secara pasif dan bersifat sukarela (voluntary application), artinya bahwa semua permohonan pendaftaran diterima dengan tidak terlalu mengadakan pemeriksaan secara substantif mengenai materi Aplikasi Ciptaan, kecuali jika sudah jelas ternyata ada pelanggaran atas syarat Hak Cipta.

Sebetulnya dalam UUHC 2002 tentang Hak Cipta menganut sistem deklaratif, namun terdapat ketentuan Pendaftaran Ciptaan yang sebetulnya bertentangan dengan sistem deklaratif. Mekanisme atau Konsep registrasi sebetulnya adalah kelanjutan dari perlindungan atas Hak Kekayaan Intelektual dengan sistem konstitutif (Constitutive Principal) dimana kepemilikan suatu Hak Kekayaan Intelektual diperoleh karena suatu pendaftaran pertama 
kali (first to file). Sistem Konstitutif ini pada umumnya dikhususkan untuk proteksi dibidang Hak Kekayaan Industrial (Industrial Property Right) yang terdiri atas Paten (Patents), Merek (Trademarks), Desain Industri (Industrial Designs).

Dengan demikian, berdasarkan kerangka pemikiran ini sementara bahwa dengan adanya ketentuan Pendaftaran Ciptaan sebagaimana diatur dalam UUHC 2002 menyebabkan dilanggarnya Asas Deklaratif (declarative principle) yaitu suatu Ciptaan dilindungi sejak pertama kali dipublikasikan.

\section{E. Penutup}

\section{Kesimpulan}

Berdasarkan pembahasan tersebut di atas, ketentuan Pendaftaran Ciptaan sebagaimana dimaksud dalam UUHC 2002 sebagai hukum normatif tentang Hak Cipta di Indonesia. Dengan adanya ketentuan Pendaftaran Ciptaan ini, memberikan konsekuensi Kantor Ditjen HKI memiliki kewenangan berdasarkan UndangUndang untuk mengelola Pendaftaran Ciptaan tersebut termasuk administrasi yaitu Kantor Ditjen HKI bertindak menerima, memeriksa dan menerbitkannya dalam Daftar Umum Ciptaan. Konsekuensi dari ketentuan tentang Pendaftaran Ciptaan ini Kantor Ditjen HKI bertindak selaku Pemeriksa dan menentukan suatu karya cipta tersebut layak atau tidak layak untuk didaftar.

Prinsip Deklaratif dalam Perlindungan Hak Cipta berdasarkan ketentuan hukum internasional dan doktrin hukum yang berlaku dalam praktek perlindungan Hak Kekayaan Intelektual dimana secara universal mengacu pada keberlakukan ketentuan konvensi internasional di bidang Hak Cipta khususnya Konvensi Bern, dimana setiap ciptaan sudah mendapatkan perlindungan secara otomatis (automatic protection) sejak Ciptaan menjadi nyata (real expression), perlindungannya diberikan langsung tanpa bergantung dari negara asal pencipta (direct and independent protection). Pemberlakukan ketentuan ini berlaku sama bagi seluruh negara-negara yang telah meratifikasi Konvensi Bern termasuk negara-negara anggota WTO yang juga menandatanggani TRIPS Agreement. Dengan demikian tidak diperlukan intervensi Negara termasuk suatu Negara membentuk suatu sistem registrasi suatu karya cipta yang selanjutnya menjadi bukti atau formalitas suatu kepemilkan ciptaan.

Hubungan antara Pendaftaran Ciptaan berdasarkan UUHC 2002 tentang Hak Cipta dilakukan dengan tetap diberlakukan secara negatif-deklaratif, dengan demikian ketentuan Pendaftaran Ciptaan tersebut menyebabkan dilanggarnya asas kepemilikan karya cipta diperoleh sejak ciptaan tersebut pertama kali dipublikasikan (Declarative Principle).

\section{Saran}

Perlu meneliti kembali apakah perlindungan hukum bidang HKI khususnya Hak Cipta, berdasarkan beberapa perundang-undangan nasional terutama Undang-Undang Hak Cipta No. 19 Tahun 2002 khususnya dengan mengkaji kembali secara juridis normatif ketentuan tentang Pendaftaran Ciptaan apakah telah sesuai dengan kaidah-kaidah hukum yang berlaku di kalangan masyarakat internasional, khususnya pengaturan seperti yang ditetapkan dalam perjanjian TRIPs and Counterfeit Goods, yang telah diratifikasi oleh Indonesia dengan UndangUndang No. 7 tahun 1994. 


\section{DAFTAR PUSTAKA}

\section{Buku}

Attorney General's, Department Copyright Law Australia, Short Guide Copyrights Information, (Attorney General's Department Copyright Law in Australia, January 2000).

CAL (Copyright Agency Ltd), Copyright Information Sheet, (Copyright Agency Ltd, $2^{\text {nd }}$ Edition, Sydney, 2000).

Cornish, W. R., Intellectual Property, Patent, Copyright, Trade Marks and Allied Rights, (Sweet \& Maxwell, $2^{\text {nd }}$ Edition, 1989).

Damian, Eddy. Hukum Hak Cipta, (Bandung: PT. Alumni, Cet. Kedua, 2004).

Friedman, W, Legal Theory, (London: Steven \& Sons Limited, 1960).

Galaner, Marc.,"The Modernization of Law The Dynamic of Growth" dalam Syamsudin, Hukum Adat dan Modernisasi Hukum, (Yogyakarta: FH UII, Cet. Pertama, 1998).

Hartono, Sunaryati, "Sejarah Pekembangan Hukum Nasional Indonesia Menuju Sistem Hukum Nasional", Makalah, 1991.

Hasan, Djuhaedah, Lembaga Jaminan Kebendaan bagi Tanah dan Benda Lain yang melekat pada Tanah dalam Konsepsi Penerapan Asas Pemisahan Horizontal, (Bandung: Citra Aditya Bakti, Cet. Pertama, 2000).

Kesowo, Bambang, Pengantar Umum Mengenai HAKI di Indonesia, (Jakarta: Sekretariat Negara RI., terbit tanpa Tahun).

Kusumaatmadja, Mochtar., Hukum, Masyarakat dan Pembinaan Hukum Nasional, (Bandung: Bina Cipta, Cet.Pertama, 1976).

Konsep-Konsep Hukum Dalam Pembangunan, (Bandung: PT. Alumni, Cetakan Keempat, 2002).

Lehman, A, Bruce., Intellectual Property and The National Information Infrastructure., The report of the Working Group on Intellectual Property Rights, September 2003.
Margono, Suyud, Hukum dan Perlindungan Hak Cipta, (Jakarta: Novindo Pustaka Mandiri., Cet. Pertama, Jakarta, 2003).

Mayana, Ranti Fauza., Perlindungan Desain Industri di Indonesia dalam Era Perdagangan Bebas, (Jakarta: PT. Gramedia Widiasarana Indonesia (Grasindo), Cet. Pertama, 2004)

Rahardjo Satjipto, Ilmu Hukum, (Bandung: Alumni, Cet. Pertama, Bandung, 1982).

Rasjidi, Lili., Dasar-dasar Filsafat Hukum, (Bandung: Citra Aditya Bakti, Cet. Kedua, 1996).

Richardson, Megan, etc., The Benefits and Costs of Copyrights: an Economic Perspective., Discussion Papers for The Centre for Copyright Studies Ltd., (Australia, Published in June 2000).

Ricketson, Stainforth and M. Richardson, Intellectual Property: Cases, Materials and Commentary, (Butterwoths, $2^{\text {nd }}$ edition, 1998.)

Sumantoro, Hukum Ekonomi, (Jakarta UI Press, Cet. Kedua, 1986).

Stewart, S, International Copyright and Neighboring Right, (2d Edition, 1989).

World Intellectual Property Organization, General Information, (Geneva: WIPO Publication No. 400 (E), 1993).

\section{Peraturan}

Agreement on Trade - Related Aspects of Intellectual Property Right, Marrakesh, 15 April 1994.

Bern Convention for the Protection of Literary and Artistic Works, Paris Act of July 24, 1971 as amended on September 28, 1979.

Undang-Undang No. 7 Tahun 1994 tentang Pengesahan Agreement Establishing The World Trade Organization (Persetujuan Pembentukan Organisasi Perdagangan Dunia).

Undang-Undang No. 19 Tahun 2002 tentang Hak Cipta 